This is an author produced version of a paper published in Integrative Zoology.

This paper has been peer-reviewed but may not include the final publisher proof-corrections or pagination.

Citation for the published paper:

Magnusson M,Samelius G, Hörnfeldt B, Ecke F. (2019) Diet shift in bank voles induced by competition from grey-sided voles?. Integrative Zoology. Volume: 14, Number: 4, pp 376-382.

https://doi.org/10.1111/1749-4877.12369.

Access to the published version may require journal subscription.

Published with special permission from: International Society of Zoological Sciences, Institute of Zoology/Chinese Academy of Sciences and John Wiley \& Sons Australia, Ltd.

Standard set statement from the publisher:

"This is the peer reviewed version of the above article, which has been published in final form at https://doi.org/10.1111/1749-4877.12369. This article may be used for noncommercial purposes in accordance with Wiley Terms and Conditions for SelfArchiving."

Epsilon Open Archive http://epsilon.slu.se 


\section{Diet shift in bank voles induced by competition from grey-sided voles?}

\section{Magnus Magnusson $^{1 *}$, Gustaf Samelius ${ }^{2}$,3 Birger Hörnfeldt $^{1}$, Frauke Ecke ${ }^{1}$}

${ }^{1}$ Department of Wildlife, Fish, and Environmental Studies, Swedish University of Agricultural Sciences, Umeå, Sweden.

${ }^{2}$ Snow Leopard Trust, 4649 Sunnyside Avenue North, Seattle, USA

${ }^{3}$ Department of Ecology, Swedish University of Agricultural Sciences, 73091 Riddarhyttan, Sweden.

* Corresponding author:

Address: Department of Wildlife, Fish, and Environmental Studies, SLU, SE-901 83 Umeå, Sweden

Email: magnus.magnusson@slu.se; Telephone no: +46(0)73 0215266 


\section{ABSTRACT}

Grey-sided voles (Myodes rufocanus Sundevall, 1846) and bank voles (Myodes glareolus Schreber, 1780) co-exist in boreal forests in northern Scandinavia. Previous studies suggest that the two species interact interspecifically, the grey-sided vole being the dominant species. We tested the hypothesis that bank voles shift their diet due to competition with the dominant grey-sided vole by studying stable isotope ratios in both species. Muscle samples were taken from voles in patches of old forest occupied by only bank voles and patches of old forest occupied by both grey-sided voles and bank voles. We found that (1) stable isotope ratios of bank voles differed in areas with and without grey-sided voles and that (2) the stable isotope ratios of bank voles were more similar to those of grey-sided voles in areas where grey-sided voles were absent. Our data suggests that grey-sided voles forced bank voles to change their diet due to interspecific competition.

Key words: Competition, Diet shift, Myodes glareolus, Myodes rufocanus, Stable isotopes

\section{INTRODUCTION}

Environmental conditions and available resources limit the fundamental niche of species, while symbiotic relationships, competition and predation form a species' realized niche (Hutchinson 1957; Begon et al. 2006). The classic theory of species co-existence and niche differentiation was developed using a two-species competition system (Volterra 1926; Lotka 1932; Tokeshi 1998). In recent literature, the importance of niche differences for 
maintaining species diversity has been discussed (Levine \& HilleRisLambers 2009). The realized dietary niche can shift between sites for different species suggesting that species may be able to adjust their diets to minimize foraging competition (Hamel et al. 2013; Baltensperger et al. 2015).

Prolonged interspecific competition can result in resource partitioning among species (Roughgarden 1976; Schoener 1983). By using stable isotope analysis to understand resource partitioning, Calandra et al. (2015) showed that the diet of arvicoline rodents was structured according to phylogeny. As a consequence of shared resources, interspecific competition between two related species, the Eurasian red squirrel (Sciurus vulgaris Linnaeus, 1758) and the alien grey squirrel (Sciurus carolinensis Gmelin, 1788), occurred when the food became limited (Wauters et al. 2002). Similarly, when food resources were plentiful, American mink (Mustela vison Schreber, 1777) became more generalistic in their diet to avoid competition with otters (Lutra lutra Linnaeus, 1758) (Clode and Macdonald 1995).

Food supply is also an important predictor of reproductive success of most microtine rodents (Koskela et al. 1998). Generally, microtine rodents tend to be limited by food and have a low-quality food diet (Ostfeld 1985). As food is of such importance for the ecology of microtine rodents, it is crucial to get a better understanding if interspecific competition leads to changes in diet.

In boreal forests of northern Sweden, bank voles (BVs) and grey-sided voles (GSVs) coexist. The GSV is the larger (Henttonen et al. 1977) and dominant species (Johannesen et al. 2002). Consequences for BVs when co-existing with the GSV are poorly understood but female GSVs may limit the breeding density of BVs (Löfgren 1995) and habitat selection 
of the BV is affected by the presence of GSVs (Johannesen \& Mauritzen 1999). Expected negative effects on demography parameters such as survival and recruitment of BVs due to interaction with the GSV were investigated in south-central Norway but no effect was found (Johannesen 2003). In contrast, red-backed voles (Myodes rutilus), a closely related species to the BV that occupy a similar ecological niche in the sub-Arctic small mammal community, was kept at low densities due to interspecific competition from the dominant GSV (Viitala 1984).

Stable isotope analyses have been used widely in ecological studies to study spatial and temporal variability in diet (Dalerum \& Angerbjörn 2005; Baltensperger et al. 2015; Ehrich et al. 2015) and are based on the fact that stable isotope ratios in animal tissues reflect those of their food (Hobson 1999; Kelly 2000). The objective of this study was to investigate whether competition with the larger and more dominant GSV affected the diet of the BV. As a proxy, we examined differences in the diet of BVs by comparing stable isotope ratios $\left(\delta^{13} \mathrm{C}(\%)\right.$ and $\left.\delta^{15} \mathrm{~N}(\%)\right)$ in BV muscle tissues in areas with and without GSVs. We also examined stable isotope ratios of the GSVs for similarities in diet between the two species. Stable isotope ratios reflect diet assimilated over time and vary between tissues in relation to their metabolic turn-over rate (DeNiro \& Epstein 1978). Stable isotope signatures therefore reflect relatively long-term dietary composition when compared to traditional methods of estimating dietary composition such as stomach and scat content (DeNiro \& Epstein 1978). 


\section{MATERIALS AND METHODS}

\section{Study area and vole samples}

This study was conducted in the inland of Västerbotten County in northern Sweden in late September and October 2010 (Figure 1). We collected 20 grey-sided voles (GSVs) and 40 bank voles (BVs) by snap-trapping in eight study areas following the methods used within the National Environmental Monitoring Program (Hörnfeldt 1978, 1994, 2004; Ecke 2018). Twenty of the BVs were collected in study areas where there were no GSVs whereas the remaining BVs were collected in study areas where they coexisted with GSVs (Magnusson et al. 2013). All study areas were within patches of old coniferous forest of moist and mesic type (Arnborg 1990). The study areas with GSVs were generally characterized by many boulders and a dominance of old Scots pine trees (Pinus sylvestris; see detailed information on habitat requirement of GSVs in Magnusson et al. 2013). The field layer in all study areas contained a high proportion of ericoid dwarf shrubs. We did a vegetation inventory one year later than the vole trappings, in late September and October 2011. We do not expect the vegetation cover to change radically in a year in old boreal forests. We measured the cover of bilberry (Vaccinium myrtillus), cowberry (Vaccinium vitis-ideae), grasses, ground lichens, tree lichens and mosses in ten quadratic plots, with $2.5 \mathrm{~m}$ sides, $10 \mathrm{~m}$ apart and centered on the 10 trap-stations in the transect located in each study area. The cover was measured according to a 5-graded scale: $1=0 \%$; $2>0-12 \% ; 3>12-25 \% ; 4>25$ $50 \% ; 5>50 \%$ (See detailed information of the vegetation inventory in Magnusson et al. 2013). 


\section{Study species}

BVs and GSVs are forest living species: the GSV is a habitat specialist, preferring boulder rich old pine forest (Magnusson et al. 2013), while the BV is a habitat generalist occurring in many habitat types but with higher winter survival in old forests (Ecke et al. 2002; Savola et al. 2013). Ericoid dwarf shrubs (within the family Ericaceae) are important food for GSVs (Kalela 1957; Soininen et al. 2013), especially bilberry in autumn and winter (Hansson \& Larsson 1978; Dahlgren et al. 2007). The BV also prefers to eat mature Vaccinium-berries in late summer and autumn (Hansson \& Larsson 1978), a time of the year when BVs are mostly herbivorous (Hansson 1985). Seasonal variation in food abundance also results in a shift towards fruticose arboreal lichens in winter for BVs (Hansson 1985; Viro \& Sulkava 1985; Ecke et al. 2018).

\section{Stable isotope analyses}

The metabolic turn-over rate of muscle is about one month (Hobson 1999), so stable isotope signatures of the vole tissues in our study thus represented the diet in late August and September since the voles were collected in late September and October. Stable isotope analyses were performed by the Stable Isotopes in Nature Laboratory (SINLAB) at University of New Brunswick in Canada and were performed using Continuous Flow Isotope Mass Spectrometry (CFIRMS) technology. Stable isotope ratios are expressed in $\delta$ notation as parts per thousand (\%o) deviations (see equation in Kelly 2000) from Peedee Belemnite (PDB; $\left.\delta^{13} \mathrm{C}\right)$ and atmospheric air $\left(\delta^{15} \mathrm{~N}\right)$. PDB is the international carbon isotope standard based on the fraction of heavy and light isotopes in marine fossils from the Peedee 
limestone formation in South Carolina (Craig 1957), while atmospheric nitrogen is the standard for nitrogen (Ehleringer \& Rundel 1989). For most tissues of plants and animals the $\delta^{13} \mathrm{C}$ value is negative due to lower ${ }^{13} \mathrm{C} /{ }^{12} \mathrm{C}$ ratio than PDB and positive for $\delta^{15} \mathrm{~N}$ due to a higher ratio of 15N/14N than the atmospheric nitrogen standard (Kelly 2000).

\section{Statistical analyses}

We examined whether stable isotope ratios of BVs differed between areas with and without GSVs by a MANOVA (Proc GLM, SAS Institute Inc. 1990, $n=40$ BVs from 8 study areas). In addition, to examine specifically for differences in $\delta^{13} \mathrm{C}(\%)$ and $\delta^{15} \mathrm{~N}$ (\%) respectively for BVs in areas with and without GSVs, we used two general linear models (SAS Institute Inc. 1990, n = $40 \mathrm{BVs}$ ). We also examined whether the isotopic signatures of GSVs differed between the four study areas they occurred on by performing a MANOVA (Proc GLM, SAS Institute Inc. 1990; $\mathrm{n}=20$ GSVs). Similarly by using two separate MANOVAs, we also examined whether the isotopic signatures of BVs differed between the four study areas with GSVs ( $=20 \mathrm{BVs}$ ), and if the isotopic signatures of BVs differed between the four study areas without GSVs ( $\mathrm{n}=20 \mathrm{BVs}$ ). We used Mann-Whitney U-tests (TIBCO Software Inc.) to investigate whether study areas with GSVs and BVs differed from study areas with only BVs regarding mean cover of bilberry, cowberry, grasses, tree lichens, ground lichens and mosses. 


\section{RESULTS}

Stable isotope ratios (and thus diet) of bank voles (BVs) differed between areas with and without grey-sided voles (GSVs) $\left(F_{2,37}=21.16, P<0.001\right.$, Figure 2$)$. More specifically, the difference was significant for $\delta^{13} \mathrm{C}(P<0.0001)$ but not for $\delta^{15} \mathrm{~N}(P=0.23)$. During coexistence, stable isotope ratios of BVs were more different from those of GSVs than when BVs were alone (Figure 2). Moreover, stable isotope ratios differed between study areas for GSVs $\left(\mathrm{F}_{6,30}=16.25, P<0.001\right)$ and BVs from areas with GSVs $\left(\mathrm{F}_{6,30}=5.14, P=0.001\right)$ and without GSVs $\left(\mathrm{F}_{6,30}=12.03, P<0.001\right)$. GSVs from the same study areas showed similar patterns in stable isotope ratios, as did BVs mostly (Figure 3).

We did not find any statistical difference in mean cover of bilberry $(P=0.5)$, cowberry ( $P$ $=0.8)$, tree lichens $(P=0.7)$, or mosses $(P=0.2)$ between study areas with and without GSVs. However, there was a larger mean cover of ground lichens in study areas with GSVs $(P<0.05)$ while grasses were more common in study areas from whichGSVs were absent $(P<0.05)$

\section{DISCUSSION}

Analyses of stable isotope ratios have been used widely in ecological studies, based on the fact that the ratios reflect those of the species' food (Hobson 1999; Kelly 2000). In this study, we found that the stable isotope ratios of bank voles (BVs) were different on study areas with grey-sided voles (GSVs) compared to areas without GSVs. The stable isotope ratios of BVs shifted away from those of the GSV when the species co-existed. We suggest 
that the change in isotope ratios of the BVs was caused by competition with GSVs, forcing BVs to change their diet when coexisting with the larger and more dominant species. Similar type of diet shifts, likely caused by competition and food resources, have been found in other species systems (e.g Werner \& Hal 1976; Alatalo et al. 1985; Clode \& Mcdonald 1995).

Normally, the diet of the two species contain a high proportion of ericoid dwarfs shrubs (Hansson \& Larsson 1978; Dahlgren et al. 2007; Soininen et al. 2013). Ericoid dwarf shrubs were common in all of our study areas and we did not find any difference in ground cover of either bilberry or cowberry between study areas with and without GSVs. However, we found a difference in the cover of grasses and ground lichens between areas with and without GSVs. Grasses were more common in areas with only BVs but since the BVs ate food that was more similar to GSVs in those areas than in areas where they co-existed (Figure 2), it is unlikely that grasses were responsible for the change in diet. Ground lichens were more common in areas with GSVs but like grasses, they are not the preferred food items of either GSVs or BVs (Hansson \& Larsson 1978; Hansson 1979; Viro \& Sulkava 1985). Therefore, we believe it to be unlikely that the voles competed for feeding on ground lichens or grasses. Anyway, we suggest that the diet shift was caused by food competition, maybe for bilberry, although we cannot yet pinpoint how the difference in $\delta^{13} \mathrm{C}$ have arisen.

We do not know the stable isotope ratios of the potential food of the voles and therefore not the different food types consumed by the voles. However, the difference in $\delta^{13} \mathrm{C}$ between 
BVs with and without GSVs, may be linked to a difference in the isotopic signature of the different plants that the animals consumed (Kelly 2000). For example, lichens and fungi generally have high $\delta^{13} \mathrm{C}$-values (Calandra et al. 2015). As BVs also consume lichens, especially arboreal lichens in trees (Hansson 1985; Viro \& Sulkava 1985), BVs may have higher $\delta^{13} \mathrm{C}$-values in areas with GSVs if they due to competition from GSVs shift their food from bilberry to lichens. However, the variation in the isotopic space is large for all plant types (Calandra et al. 2015) making any explanation of the difference in $\delta^{13} \mathrm{C}$ for BVs in areas with and without GSVs mainly speculative. A removal experiment, removing GSVs from BV sites, while studying the diet of BVs would provide further insight into a potential competitive diet shift. Our study design did not allow for such experimental manipulation.

Our result suggesting a diet shift for BVs when coexisting with GSVs is novel, as previous studies on competition between the two species have either been looking at space use (Löfgren 1995; Johannesen \& Mauritzen 1999), or dominance interactions due to size and aggressiveness in so called dyadic encounters (Johannesen et al. 2002). Our study thus adds further information on interspecific interactions between these microtine rodents. We suggest that future research should focus on gaining a better understanding of diet shifts induced by competition, preferably by using stable isotope analyses and, if possible, removal experiments. In addition, more studies of how diet shifts differ with seasonal variation in food availability are needed. 


\section{ACKNOWLEDGMENTS}

We thank the anonymous reviewers for their constructive comments. Financial support was received from stiftelsen Oscar och Lili Lamms minne, from Helge Ax:son Johnsons stiftelse and from the Swedish Research Council FORMAS (Dnr 2017-00867). A permit for trapping small mammals in nature reserves was provided by the Västerbotten County Administration Board.

\section{REFERENCES}

Alatalo RV, Gustafsson L, Linden M, Lundberg A (1985). Interspecific competition and niche shifts in tits and the goldcrest: an experiment. Journal of Animal Ecology 54, 97784.

Arnborg T (1990). Forest types of northern Sweden. Vegetatio 90, 1-13.

Baltensperger AP, Huettman F, Hagelin JC, Welker JM (2015). Quantifying trophic niche spaces of small mammals using stable isotopes $\left(\delta^{15} \mathrm{~N}\right.$ and $\left.\delta^{13} \mathrm{C}\right)$ at two scales across Alaska. Canadian Journal of Zoology 93, 579-88.

Begon M, Townsen CR, Harper JL (2006). Ecology: From individuals to ecosystems, 4th edn. Blackwell publishing Ltd, Oxford, UK.

Calandra I, Labonne G, Mathieu O et al. (2015). Isotopic partitioning by small mammals in subnivium. Ecology and Evolution 5, 4132-40.

Clode D, Macdonald DW (1995). Evidence for food competition between mink (Mustela vison) and otter (Lutra lutra) on Scottish islands. Journal of Zoology 237, 435-44. 
Craig H (1957). Isotopic standards for carbon and oxygen and correction factors for massspectrometric analysis of carbon dioxide. Geochimica et Cosmochimica Acta 12, 133-49.

Dahlgren J, Oksanen L, Sjödin M, Olofsson J (2007). Interactions between gray-sided voles (Clethrionomys rufocanus) and bilberry (Vaccinium myrtillus), their main winter food plant. Oecologia 152, 525-32.

Dalerum F, Angerbjörn A (2005). Resolving temporal variation in vertebrate diets using naturally occurring stable isotopes. Oecologia 144, 647-58.

DeNiro MJ, Epstein S (1978). Influence of diet on the distribution of carbon isotopes in animals. Geochimica et Cosmochimica Acta 42, 495-506.

Ecke F, Löfgren O, Sörlin D (2002). Population dynamics of small mammals in relation to forest age and structural habitat factors in northern Sweden. Journal of Applied Ecology 39, 781-92.

Ecke F (2018). Swedish National Environmental Monitoring Program for small rodents. [Cited 15 Jun 2018]. Available from URL: https://www.slu.se/institutioner/vilt-fiskmiljo/miljoanalys/miljoovervakning-av-smagnagare/.

Ecke F, Berglund MMÅ, Rodushkin I et al. (2018). Seasonal shift of diet in bank voles explains trophic fate of anthropogenic osmium? Science of the Total Environment 624, $1634-9$.

Ehleringer JR, Rundel PW (1989). Stable Isotopes: history, units, and instrumentation. In: Rundel PW, Rundel JR, Nagy KA, eds. Stable isotopes in ecological research. SpringerVerlag, New York. pp. 1-16.

Ehrich D, Ims RA, Yoccoz NG et al. (2015). What can stable isotope analysis of top predator tissues contribute to monitoring of tundra ecosystems? Ecosystems 18, 404-16. 
Hamel S, Killengreen ST, Henden J-A, Yoccoz NG, Ims RA (2013). Disentangling the importance of interspecific competition, food availability, and habitat in species occupancy: Recolonization of the endangered Fennoscandian arctic fox. Biological Conservation 160, 114-20.

Hansson L, Larsson T-B (1978). Vole diets on experimentally managed reforestation areas in Northern Sweden. Ecography 1, 16-26.

Hansson L (1979). Condition and diet in relation to habitat in bank voles Clethrionomys glareolus: Population or community approach? Oikos 33, 55-63.

Hansson L (1985). Clethrionomys food: generic, specific and regional characteristics. Annales Zoologici Fennici 22, 315-318.

Henttonen H, Kaikusalo A, Tast J, Viitala J (1977). Interspecific competition between small rodents in subarctic and boreal ecosystems. Oikos 29, 581-90.

Hobson KA (1999). Tracing origins and migration of wildlife using stable isotopes: a review. Oecologia 120, 314-326.

Hutchinson GE (1957). Concluding remarks. Cold Spring Harbor Symposia on Quantitative Biology 22, 415-27.

Hörnfeldt B (1978). Synchronous population fluctuations in voles, small game, owls, and tularemia in Northern Sweden. Oecologia 32, 141-52.

Hörnfeldt B (1994). Delayed density dependence as a determinant of vole cycles. Ecology 75, 791-806.

Hörnfeldt B (2004). Long-term decline in numbers of cyclic voles in boreal Sweden: analyses and presentation of hypotheses. Oikos 107, 376-92. 
Johannesen E, Mauritzen M (1999). Habitat selection of grey-sided voles and bank voles in two sub-alpine populations in southern Norway. Annales Zoologici Fennici 36, 215-222.

Johannesen E, Brudevoll J, Jenstad M, Korslund L, Kristoffersen S (2002). Behavioural dominance of grey-sided voles over bank voles in dyadic encounters. Annales Zoologici Fennici 39, 43-47.

Johannesen E (2003). Intra- and interspecific density dependence in the survival and recruitment of grey-sided (Clethrionomys rufocanus) and bank voles (C. glareolus). Annales Zoologici Fennici 40, 35-44.

Kalela O (1957). Regulation of reproduction rate in subarctic populations of the vole Clethrionomys rufocanus (Sund.). Annales Academiae Scientiarum Fennicae, Series A, IV. Biologica 34, 1-60.

Kelly JF (2000). Stable isotopes of carbon and nitrogen in the study of avian and mammalian trophic ecology. Canadian Journal of Zoology 78, 1-27.

Koskela E, Jonsson P, Hartikainen T, Mappes T (1998). Limitation of reproductive success by food availability and litter size in the bank vole, Clethrionomys glareolus. Proceedings of the Royal Society B 265, 1129-34.

Levine JM, HilleRisLambers J (2009). The importance of niches for the maintenance of species diversity. Nature 461, 254-57.

Lotka AJ (1932). The growth of mixed populations: two species competing for a common food supply. Journal of the Washington Academy of Sciences 22, 461-69.

Löfgren O (1995). Spatial organization of cyclic Clethrionomys females: Occupancy of all available space at peak densities? Oikos 72, 29-35. 
Magnusson M, Bergsten A, Ecke F, Bodin Ö, Bodin L, Hörnfeldt B (2013). Predicting grey-sided vole occurrence in northern Sweden at multiple spatial scales. Ecology and Evolution 3, 4365-76.

Ostfeld RS (1985). Limiting resources and territoriality in microtine rodents. The American Naturalist 126, 1-15.

Roughgarden J (1976). Resource partitioning among competing species - a coevolutionary approach. Theoretical Population Biology 9, 388-424.

SAS Institute Inc. (1990). SAS user's guide, 6th edn. SAS publishing, Cary, North Carolina, USA.

Savola S, Henttonen H, Lindén H (2013). Vole Population Dynamics During the Succession of a Commercial Forest in Northern Finland. Annales Zoologici Fennici 50, 79-88.

Schoener TW (1983). Field Experiments on Interspecific Competition. The American Naturalist 122, 240-285.

Soininen EM, Ravolainen VT, Bråthen KA, Yoccoz NG, Gielly L, Ims RA (2013). Arctic small rodents have diverse diets and flexible food selection. PLoS ONE 8, e68128.

Tokeshi M (1998). Species Coexistence. Blackwell Sciences Ltd, Oxford, UK.

TIBCO Software Inc. Statistica (data analysis software system), version 13. [Cited 18 jun 2018]. Available from URL: http://statistica.io.

Viitala J (1984). The red vole, Clethrionomys rutilus (Pall.), as a subordinate member of the rodent community at Kilpisjarvi, Finnish Lapland. Acta Zoologica Fennica 172, 67-70.

Viro P, Sulkava S (1985). Food of the Bank Vole in Northern Finnish Spruce Forests. Acta Theriologica 30, 259-66. 
Volterra V (1926). Fluctuations in the abundance of a species considered mathematically. Nature 118, 558-60.

Wauters LA, Gurnell J, Martinoli A, Tosi G (2002). Interspecific competition between native Eurasian red squirrels and alien grey squirrels: does resource partitioning occur? Behavioral Ecology and Sociobiology 52, 332-41.

Werner EE, Hal DJ (1976). Niche shifts in sunfishes: experimental evidence and significance. Science 191, 404-06. 


\section{FIGURE LEGENDS}

Figure 1. Study areas in Västerbotten county, northern Sweden. (a) Four study areas where both GSVs (Myodes rufocanus) and BVs (Myodes glareolus) occurred (black circles) and four study areas were only BVs occurred (white circles); (b) Each study area was situated within a patch of old forest and (c) contained a $90 \mathrm{~m}$ long transect with 10 trap stations where (d) five snap-traps were placed within $1 \mathrm{~m}$ from the circle center.

Figure 2. Variation in stable isotope signatures (measured by $\delta 15 \mathrm{~N}(\%)$ and $\delta 13 \mathrm{C}(\%)$ in muscle tissues) for GSVs (Myodes rufocanus; black triangles) and BVs (Myodes glareolus; circles) at study areas with GSVs (black circles) and without GSVs (light grey circles).

Figure 3. Spatial variation in stable isotope signatures (measured by $\delta 15 \mathrm{~N}(\%)$ and $\delta 13 \mathrm{C}$ (\%) in muscle tissues) for BVs (Myodes glareolus; circles) and GSVs (Myodes rufocanus; squares) at study areas where both species occurred. Voles from Norrgravsjö shown in white, Storberget in black and other areas (Trehörningen and Brandbärsberget) in light grey. 
Figure 1

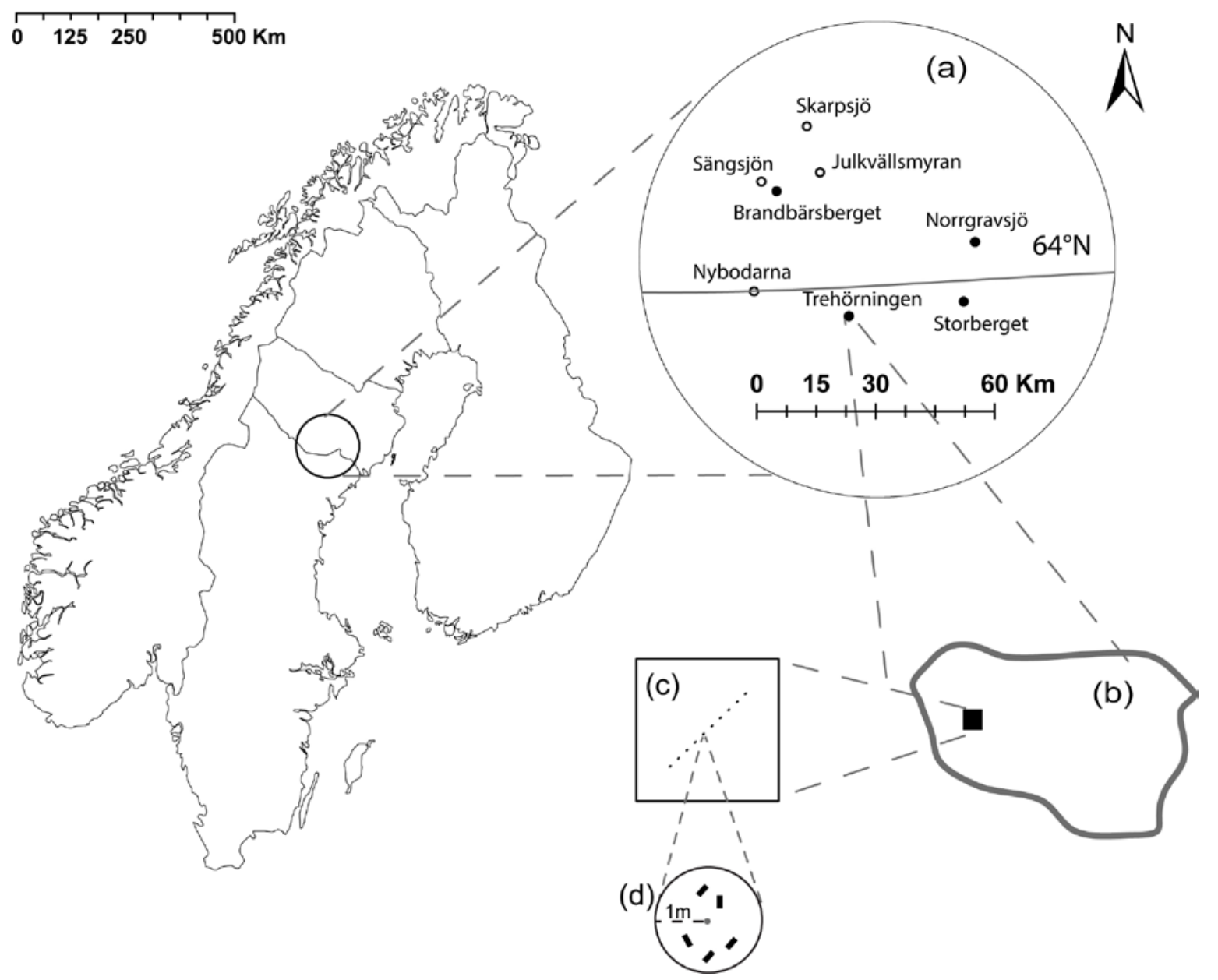


Figure 2




Figure 3

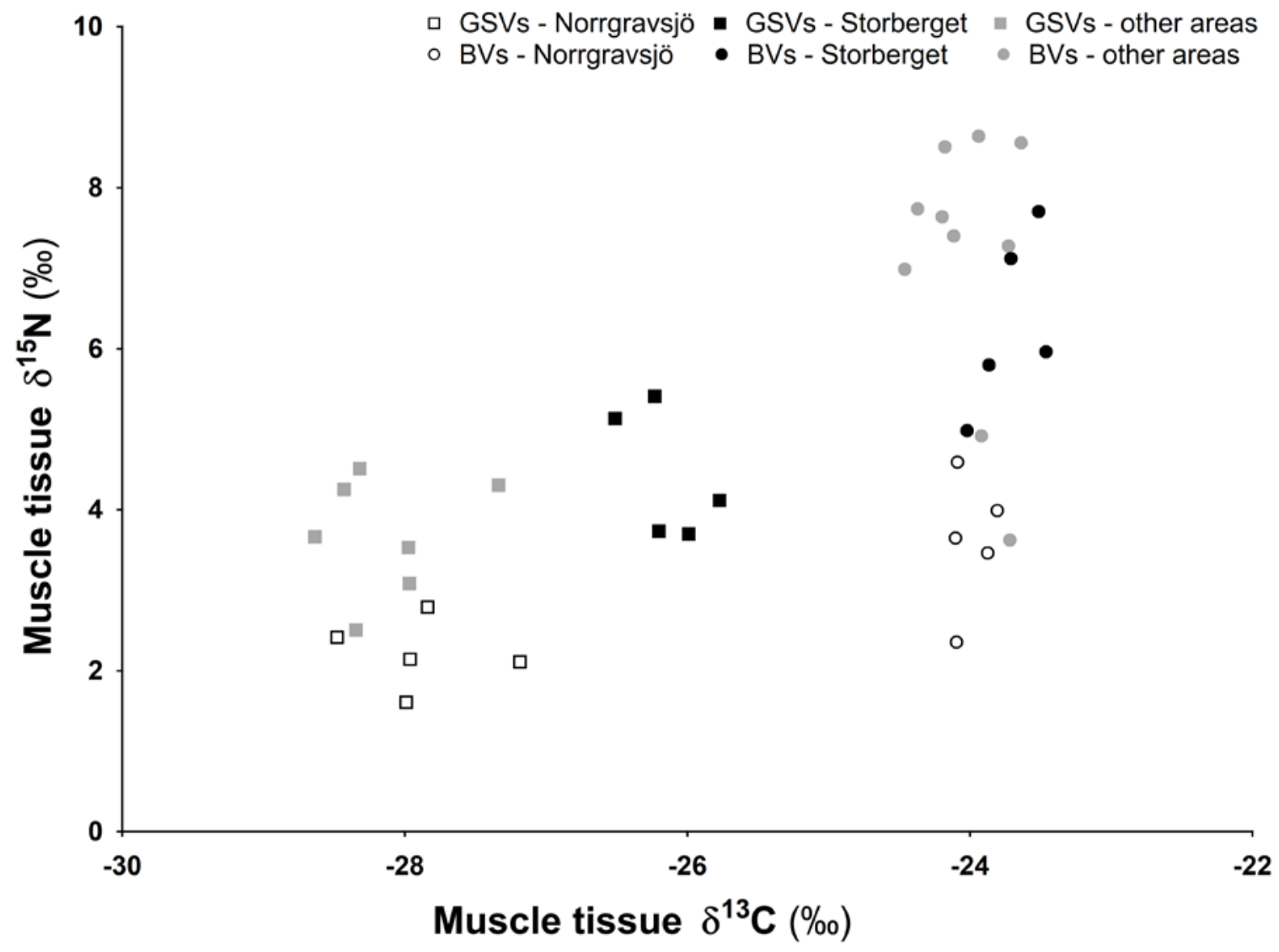

